US Army Corps

of Engineers.

Portland District

Prepared for the U.S. Army Corps of Engineers, Portland District,

under a Government Order with the U.S. Department of Energy

Contract DE-AC05-76RL01830

\title{
Performance Assessment of Suture Type in Juvenile Chinook Salmon Surgically Implanted with Acoustic Transmitters
}

\section{FINAL REPORT}

KA Deters

RS Brown

KM Carter

JW Boyd

February 2009

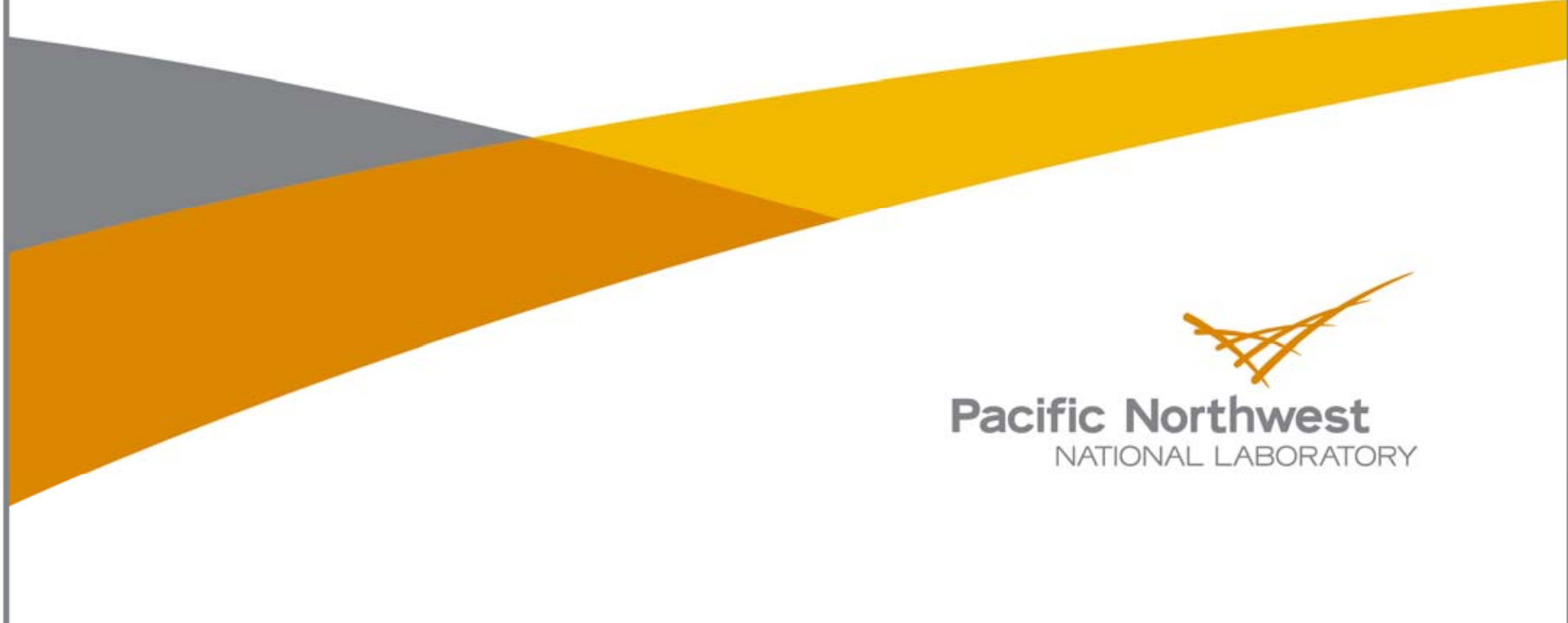




\title{
DISCLAIMER
}

This report was prepared as an account of work sponsored by an agency of the United States Government. Neither the United States Government nor any agency thereof, nor Battelle Memorial Institute, nor any of their employees, makes any warranty, express or implied, or assumes any legal liability or responsibility for the accuracy, completeness, or usefulness of any information, apparatus, product, or process disclosed, or represents that its use would not infringe privately owned rights. Reference herein to any specific commercial product, process, or service by trade name, trademark, manufacturer, or otherwise does not necessarily constitute or imply its endorsement, recommendation, or favoring by the United States Government or any agency thereof, or Battelle Memorial Institute. The views and opinions of authors expressed herein do not necessarily state or reflect those of the United States Government or any agency thereof.

\author{
PACIFIC NORTHWEST NATIONAL LABORATORY \\ operated by \\ BATTELLE \\ for the \\ UNITED STATES DEPARTMENT OF ENERGY \\ under Contract DE-AC05-76RL01830 \\ Printed in the United States of America \\ Available to DOE and DOE contractors from the \\ Office of Scientific and Technical Information, \\ P.O. Box 62, Oak Ridge, TN 37831-0062; \\ ph: (865) 576-8401 \\ fax: (865) 576-5728 \\ email: reports@adonis.osti.gov
}

\author{
Available to the public from the National Technical Information Service, \\ U.S. Department of Commerce, 5285 Port Royal Rd., Springfield, VA 22161 \\ ph: (800) 553-6847 \\ fax: (703) 605-6900 \\ email: orders@ntis.fedworld.gov \\ online ordering: http://www.ntis.gov/ordering.htm
}




\section{Performance Assessment of Suture Type in Juvenile Chinook Salmon Surgically Implanted with Acoustic Transmitters}

Final Report

KA Deters

RS Brown

KM Carter

JW Boyd

February 2009

Prepared for the

U.S. Army Corps of Engineers, Portland District, under a Government Order with the

U.S. Department of Energy

Contract DE-AC05-76RL01830

Pacific Northwest National Laboratory

Richland, Washington 99352 



\section{Summary}

The U.S. Army Corps of Engineers, Portland District, is conducting a program to aid in determining the suitability of acoustic telemetry for estimating short- and longer-term (30-60 days) juvenile-salmonid survival at Columbia and Snake River dams and through the lower Columbia River. As part of that effort, researchers at the Pacific Northwest National Laboratory (PNNL) assessed performance of seven suture types in subyearling Chinook salmon Oncorhynchus tshawytscha implanted with Juvenile Salmon Acoustic Telemetry System (JSATS) acoustic microtransmitters. In the study, conducted at the PNNL Aquatics Research Laboratory, nonabsorbable (Ethilon) and absorbable monofilament (Monocryl) and braided sutures (Nurolon, Vicryl, Vicryl Plus, Vicryl Rapide, and silk) were used to close incisions in Chinook salmon. Four surgeons performed all surgeries on fish held in water at either $12^{\circ} \mathrm{C}$ or $17^{\circ} \mathrm{C}$. The PNNL research team then quantified suture and tag retention, incision openness, wound inflammation, and wound ulceration at 7 and $14 \mathrm{~d}$ post-surgery.

An absorbable monofilament (Monocryl) exhibited greater suture retention than all other suture types at $7 \mathrm{~d}$. Both monofilament suture types (Ethilon and Monocryl) were retained better than all braided suture types at $14 \mathrm{~d}$. Incision openness and tag retention did not differ among suture types. Wound inflammation was lower for Ethilon, Monocryl, and one nonabsorbable braided suture type (Nurolon) at $14 \mathrm{~d}$. Ethilon and Monocryl had lower wound ulceration than all braided suture types at $7 \mathrm{~d}$. By $14 \mathrm{~d}$ post-surgery, wound ulceration was lower for Ethilon, Monocryl, and Nurolon than for all other suture types. Fish held in $12^{\circ} \mathrm{C}$ water had more desirable post-surgery healing characteristics (i.e., higher suture and tag retention and lower incision openness, wound inflammation, and ulceration) at 7 and $14 \mathrm{~d}$ after surgery than those held in $17^{\circ} \mathrm{C}$ water. The effect of surgeon was a significant predictor of suture and tag retention, incision openness, and wound ulceration at 7 and $14 \mathrm{~d}$ and of wound inflammation at $7 \mathrm{~d}$. This result emphasizes the importance of including surgeon as a variable in telemetry study analyses when multiple surgeons are used. Monofilaments performed better with regard to post-surgery healing characteristics in the study fish. The overall results support the conclusion that Monocryl is the best suture material to close incisions created during surgical implantation of microtransmitters in subyearling Chinook salmon. 



\section{Acknowledgments}

The authors acknowledge the support and oversight of M. Brad Eppard, the contracting officer's representative for the USACE. Craig McKinstry of PNNL provided statistical analyses. Gordon Axel, Brad Ryan, and Michelle Rub of National Oceanic and Atmospheric Administration (NOAA Fisheries) assisted with surgical implantation of transmitters. Jason Everett and Eric Hockersmith of NOAA Fisheries, Brian Bellgraph, Andrea Currie, Gayle Dirkes, Ryan Harnish, Bob Mueller, Eric Oldenburg, Katie Ovink, Jennifer Panther, John Stephenson, Abigail Welch, and Christa Woodley of PNNL provided valuable assistance. We also thank John Skalski of the University of Washington for scientific advice. Animal facilities were certified by the Association for Assessment and Accreditation of Laboratory Animal Care; animals were handled in accordance with federal guidelines for the care and use of laboratory animals, and protocols were approved by the Institutional Animal Care and Use Committee, Battelle-Pacific Northwest Division. Reference to trade names does not imply endorsement by the U.S. Government. 



\section{Contents}

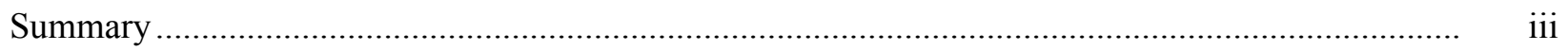

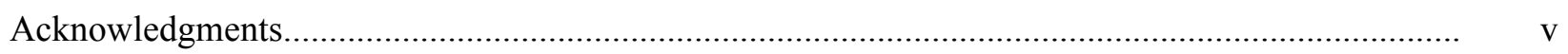

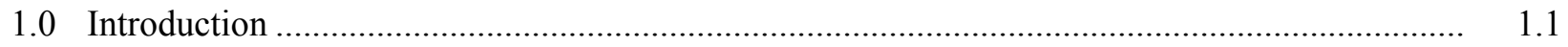

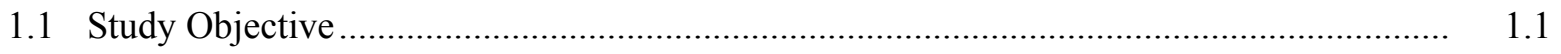

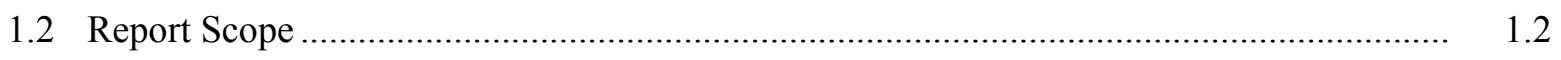

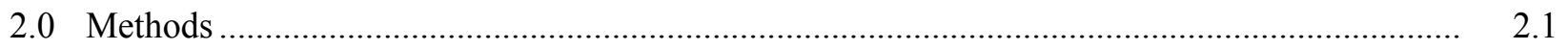

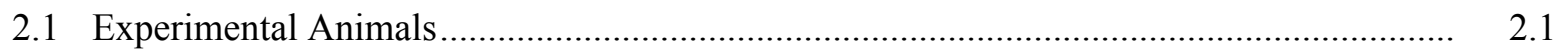

2.2 Surgical Equipment and Procedures.................................................................... 2.1

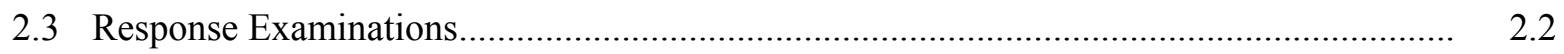

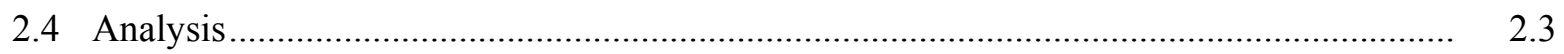

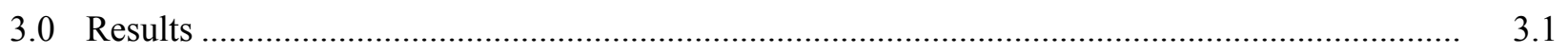

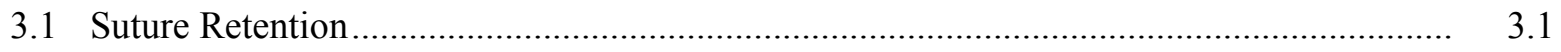

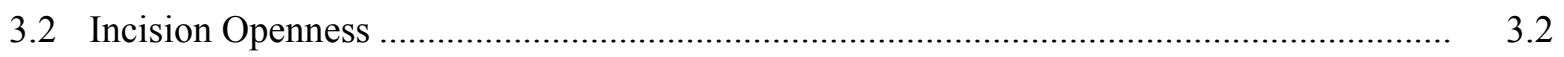

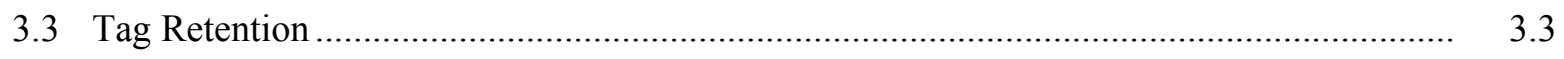

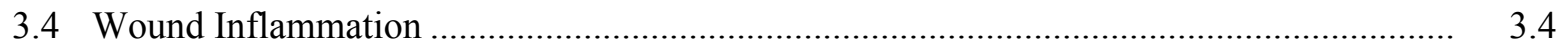

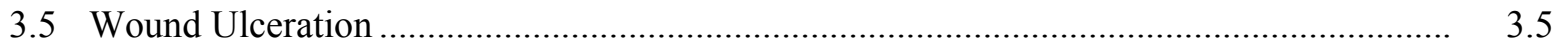

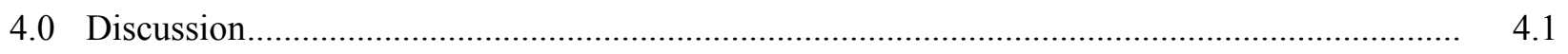

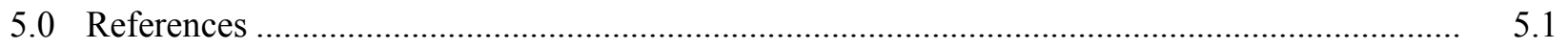




\section{Figures}

3.1 Percentage of suture retention for subyearling Chinook salmon by suture type at 7 and 14 days post-surgery.

3.2 Percentage of suture retention for subyearling Chinook salmon by surgeon at 7 and 14 days post-surgery

3.3 Mean incision openness score for subyearling Chinook salmon by suture type at 7 and 14 days post-surgery.

3.4 Percentage of tag retention for subyearling Chinook salmon by suture type at 7 and 14 days post-surgery

3.5 Mean wound inflammation for subyearling Chinook salmon by suture type at 7 and 14 days post-surgery

3.6 Mean wound ulceration for subyearling Chinook salmon by suture type at 7 and 14 days post-surgery

4.1 Percentage of suture retention for subyearling Chinook salmon by suture type and surgeon 14 days post-surgery

\section{Tables}

2.1 Properties of suture types and needles used in the study.

2.2 Rating criteria used to characterize incision openness

2.3 Rating criteria used to characterize inflammation and ulceration associated with the presence of sutures 


\subsection{Introduction}

Biotelemetry research involves attaching a device that emits an acoustic or radio signal from a tagged individual to a receiving system (Winter 1996). Acoustic and radio transmitters have been used successfully in the Snake and Columbia rivers to evaluate multiple factors associated with the passage behavior and survival of adult and juvenile salmonids in association with hydroelectric dams (Adams et al. 1996, 1997; Anglea et al. 2001; Ploskey et al. 2001; Absolon et al. 2003; Axel et al. 2004a, 2004b; Eppard et al. 2005a, 2005b; Hockersmith et al. 2005). Ideally, the attachment or presence of a transmitter should not affect the behavior or survival of tagged fish, allowing inferences from a sample of tagged fish to a population of interest. However, there is evidence that biotelemetry devices can indeed affect fish behavior, growth, and survival (Lucas 1989; Moore et al. 1990; Robertson et al. 2003; Brown et al. 2006, 2007). Therefore, studies using this technology must aim to minimize this effect.

Researchers conducting acoustic telemetry studies often implant a transmitter into the peritoneal cavity of study fish and close the incision with suture material. Ideal suture material should maintain adequate tensile strength and knot security until the surrounding tissue integrity has returned. The suture material should have minimal interference with the healing process, resist bacterial contamination, and elicit minimal foreign body reactions (Lin et al. 1996; Roush 2003). Although suture materials have been studied extensively for use in human and veterinary medicine (Lin et al. 1996; Roush 2003), comparatively little effort has been focused on suture performance in fish (Wagner et al. 2000; Hurty et al. 2002).

One survey-based article suggested that the most common suture material used in fish surgery is synthetic monofilament (Wagner and Cooke 2005). Several studies have shown that synthetic monofilaments may elicit less tissue inflammation and promote more rapid incision healing compared to silk sutures. For example, rainbow trout Oncorhynchus mykiss experienced less tissue inflammation from monofilament than from braided silk sutures (Kaseloo et al. 1992; Wagner et al. 2000). Surgical wound healing was significantly faster when monofilament sutures were used rather than silk in blue tilapia Oreochromis aureus (Thoreau and Baras 1997) and koi Cyprinus carpio (Hurty et al. 2002). However, wound healing and incision inflammation in largemouth bass Micropterus salmoides sutured with monofilament sutures did not differ from those in largemouth bass sutured with braided silk sutures (Cooke et al. 2003). Conflicting results among extant studies and an overall lack of research on the effects of different suture materials used in fish surgeries suggest more research is needed.

\subsection{Study Objective}

The objective of this study was to determine the best overall suture material to close incisions from the surgical implantation of Juvenile Salmon Acoustic Telemetry System (JSATS) acoustic microtransmitters in subyearling Chinook salmon Oncorhynchus tshawytscha. The effects of seven suture materials, four surgeons, and two water temperatures on suture retention, incision openness, tag retention, wound inflammation, and wound ulceration were quantified. The laboratory study, conducted by researchers at the Pacific Northwest National Laboratory, supports a larger effort under way for the U.S. Army Corps of Engineers, Portland District, aimed at determining the suitability of acoustic telemetry for estimating short- and longer-term (30-60 days) juvenile-salmonid survival at Columbia and Snake River dams and through the lower Columbia River. 


\subsection{Report Scope}

The methods used in the laboratory study are described in Section 2. Study results are presented in Section 3. Section 4 provides a discussion of the study outcomes. Sources cited in the text are listed in Section 5. 


\subsection{Methods}

\subsection{Experimental Animals}

Subyearling spring Chinook salmon were obtained from the Entiat National Fish Hatchery in Chelan County, Washington, and transported to the Pacific Northwest National Laboratory (PNNL) Aquatics Research Laboratory in Richland, Washington, in August 2006. Mean $\left({ }_{ \pm} \mathrm{SE}\right)$ fork length and weight of fish were $101 \pm<1 \mathrm{~mm}$ (range $=95-121 \mathrm{~mm})$ and $13.4 \pm 0.1 \mathrm{~g}$ (range $=9.8-23.7 \mathrm{~g})$, respectively. All fish were held in chilled $12^{\circ} \mathrm{C}$ well water in four 890 -L circular fiberglass tanks and fed daily to satiation (ad libitum) with Biodiet pellets (Bio-Oregon, Inc.). Prior to surgery, half of the fish were gradually acclimated to $17^{\circ} \mathrm{C}$ well water over a period of $3 \mathrm{~d}\left(\right.$ rate $\left.<2^{\circ} \mathrm{C} / \mathrm{d}\right)$. Water temperatures of $12^{\circ} \mathrm{C}$ and $17^{\circ} \mathrm{C}$ were used to simulate the mean water temperatures during outmigration of yearling and subyearling Chinook salmon, respectively, in the Columbia River Basin. Once acclimated, fish were held at $17^{\circ} \mathrm{C}$ for one week before experimentation. All fish were exposed to a $12 \mathrm{~h}$ light: $12 \mathrm{~h}$ dark photoperiod for the duration of the study. Fish were not fed within $24 \mathrm{~h}$ of surgery.

\subsection{Surgical Equipment and Procedures}

Surgeries were performed on 1,008 subyearling Chinook salmon on November 30 and December 1, 2006. Four surgeons performed all surgeries to minimize bias resulting from differences in surgeon performance. Suture type was assigned randomly (without replacement) and used to suture three consecutive fish; this order was used for the entire tagging period. Each surgeon performed surgery on three fish with the same suture type before switching to the next suture in the order. Fish from a different water temperature $\left(12^{\circ} \mathrm{C}\right.$ and $\left.17^{\circ} \mathrm{C}\right)$ were assigned to the surgeons after one full rotation of the suture order (i.e. after each surgeon completed 3 surgeries with each of 7 suture types, or 21 surgeries).

Prior to surgery, all fish were brought to stage 4 anesthesia (as described by Summerfelt and Smith 1990) using $80 \mathrm{mg}$ of tricaine methanesulfonate (MS-222)/L of water. After fork length (millimeters) and weight (grams) were obtained, fish were placed ventral side up on a foam rubber pad and supplied with a maintenance anesthesia dose of $40 \mathrm{mg} / \mathrm{L}$ MS-222. Surgical incisions were made using a BD Beaver Micro-Unitome knife with a 3-mm blade (Becton, Dickinson and Company). An incision approximately $8 \mathrm{~mm}$ long was placed $3 \mathrm{~mm}$ lateral to and parallel with the linea alba. All fish were implanted with an acoustic transmitter and a passive integrated transponder (PIT) tag (Destron Technologies). Acoustic transmitters were either 2006 model JSATS acoustic transmitters or "dummy" transmitters, both manufactured by Sonic Concepts. The 2006 model transmitters were (mean \pm standard deviation) $5.9 \pm$ $0.1 \mathrm{~mm}$ wide, $17.0 \pm 0.2 \mathrm{~mm}$ long, and $4.8 \pm 0.2 \mathrm{~mm}$ high. Transmitters had a weight in air of $0.60 \pm$ $<0.1 \mathrm{~g}(0.3 \pm<0.01 \mathrm{~g}$ in water) and a mean volume of $0.28 \mathrm{~mL}$. The dummy transmitters (weight $=0.38$ $\mathrm{g}$ in water) were the same dimensions as the 2006 model transmitters. Passive integrated transponder tags were $12.5 \mathrm{~mm}$ long, $2.07 \mathrm{~mm}$ wide, and weighed $0.11 \mathrm{~g}$ in air. Tag burden for all fish was (mean $\pm \mathrm{SE}$ ) $5.5 \pm<0.1 \%$ (range $=3.5-6.7 \%$ ). After the incision was made, the PIT tag and the acoustic transmitter were inserted into the peritoneal cavity of the fish. The incision was closed using two simple interrupted stitches secured with reinforced surgeon's knots. A reinforced surgeon's knot consisting of three double throws in alternating directions was used for all braided sutures (see Table 2.1). Ethicon (the suture manufacturer) suggests the use of additional throws when knotting monofilaments (Ethicon 2005). 
Therefore, a fourth double throw was used for Ethilon and Monocryl. After surgery, fish were released to their respective holding tanks. Feeding to satiation (ad libitum) resumed one day following surgery.

All suture types were Ethicon brand, 5-0 thickness, and were manufactured with varying needle types (Table 2.1). Suture types were chosen for this study based on high prevalence of use in telemetry studies and potential benefits to fish. Ideally, the best suture material would provide the wound apposition necessary for healing and then be quickly absorbed, causing minimal irritation to the fish. Vicryl and silk have been commonly used in telemetry studies in the Columbia River Basin and elsewhere. Vicryl Rapide was selected for its rapid absorption rate, while other sutures (Nurolon, Monocryl, and Ethilon) claimed minimal reaction with tissue. Vicryl Plus has an antibacterial agent and was chosen because it may minimize infection and inflammation of the wound. Thus, seven suture types were selected for comparison in this study.

Table 2.1. Properties of suture types and needles used in the study.

\begin{tabular}{lllll}
\hline \multirow{2}{*}{ Suture Type } & \multicolumn{2}{c}{ Properties } \\
\cline { 2 - 5 } Ethilon & Material & Absorbable & Filament & Needle \\
Monocryl & Nylon & No & Mono & Reverse cutting (FS-2) \\
Nurolon & Poliglecaprone 25 & Yes & Mono & Precision point-reverse cutting (PS-2) \\
Vicryl Rapide & Nylon & No & Braided & Precision cosmetic-conventional cutting (PC-1) \\
& $\begin{array}{l}\text { Polyglactin } 910 \\
\text { (coated) }\end{array}$ & Yes & Braided & Precision point-reverse cutting (P-3) \\
Silk (Perma-hand) & Organic protein & No & Braided & Reverse cutting (FS-2) \\
Vicryl & Polyglactin 910 & Yes & Braided & Reverse cutting (FS-2) \\
Vicryl Plus & Polyglactin 910 & Yes & Braided & Taper point (RB-1) \\
\hline
\end{tabular}

\subsection{Response Examinations}

All fish were examined at 7, 14, 34, and 63 days post-surgery. Fish were fasted for $24 \mathrm{~h}$ prior to examinations. A single evaluator graded all fish on all examination days. Examinations consisted of anesthetizing fish with $80 \mathrm{mg} / \mathrm{L}$ MS-222 and obtaining fork length (millimeters) and weight (grams). Fish were then placed ventral side up on a foam rubber pad and supplied with a maintenance anesthesia dose of $40 \mathrm{mg} / \mathrm{L} \mathrm{MS}-222$. Evaluations were made on both the anterior and posterior sutures separately as well as on the incision. Functional suture retention was assessed for all fish (response values of 0,1 , or 2 functional sutures remaining). A functional suture was defined as any suture that was present in the fish, remained knotted, and did not tear through the body wall of the fish. Tag retention was recorded as present (1) or absent (0). Incision openness was scored on a 0-4 ordinal scale for all fish, with lower numbers representing less incision openness (Table 2.2). Wound inflammation and wound ulceration each were scored on a $0-4$ ordinal scale, with lower values indicating less inflammation or ulceration of tissue along the suture location (Table 2.3). 
Table 2.2. Rating criteria used to characterize incision openness.

\begin{tabular}{cl}
\hline Rating & \multicolumn{1}{c}{ Rating Criteria } \\
\hline 0 & Incision completely closed and healed \\
1 & Incision completely closed but not healed \\
2 & Incision $<50 \%$ open \\
3 & Incision $>50 \%$ open \\
4 & Incision completely open \\
\hline
\end{tabular}

Table 2.3. Rating criteria used to characterize inflammation and ulceration associated with the presence of sutures. Inflammation was reported if skin along the suture location was red. Ulceration was reported when an open sore (depressed from the surrounding tissue) was present along the suture location.

\begin{tabular}{cl}
\hline Rating & \multicolumn{1}{c}{ Rating Criteria } \\
\hline 0 & No inflammation/ulceration \\
1 & Inflammation/ulceration at entry OR exit \\
2 & Inflammation/ulceration at both entry AND exit \\
3 & Inflammation/ulceration BETWEEN entry and exit \\
4 & Inflammation AT BOTH AND BETWEEN entry and exit \\
\hline
\end{tabular}

\subsection{Analysis}

All data were collected from the randomized and balanced factorial experiment with $\alpha=0.05$ for all analyses. Functional suture retention was analyzed using a proportional odds test. Tag retention was modeled using a logistic regression model with the experimental factors (i.e., suture type, surgeon, water temperature) along with suture retention and incision openness score as additional factors. Incision openness, wound inflammation, and wound ulceration were modeled using a multivariate normal model with the experimental factors as regression variables. Modeling of incision openness included suture retention as an additional predictor variable. Pairwise contrasts among suture types were performed when a significant suture type effect was obtained. Pairwise contrasts among surgeons were performed for suture retention. Wound inflammation and wound ulceration analyses were limited to fish retaining two functional sutures because the extent of inflammation and ulceration attributed to sutures is dependent on the presence of the suture and the length of time since the suture was lost. The exact date of suture loss and the lasting effect of a lost suture on inflammation and ulceration were unknown. 



\subsection{Results}

Most sutures (82\%) were retained through day 14; however, the majority of sutures (61\%) were absent or no longer functional by day 34 . In addition, incisions were mostly closed by day 14; there was little change in incision openness beyond that point [(mean \pm SE) $0.6 \pm<0.1,0.5 \pm 0.1$, and $0.6 \pm 0.3$ at 14,34 , and $63 \mathrm{~d}$, respectively]. Thus, results are presented for only 7 and $14 \mathrm{~d}$ after surgery.

\subsection{Suture Retention}

Retention of sutures differed significantly $(P<0.001)$ among suture types at 7 and $14 \mathrm{~d}$ (Figure 3.1$)$. Seven days after surgery, suture retention was significantly $(P \leq 0.001)$ higher for Monocryl and lower $(P$ $\leq 0.006)$ for Nurolon than all other suture types; there was no significant $(P>0.05)$ difference among all other pairwise comparisons. By day 14 , Monocryl and Ethilon had similar $(P=0.880)$ suture retention, which was significantly $(P \leq 0.003)$ higher than all other suture types (Figure 3.1$)$. Similar to day 7,14 days after surgery suture retention was significantly $(P<0.001)$ lower for Nurolon than all other suture types and all other pairwise comparisons between suture types were not significantly different $(P>0.05)$.
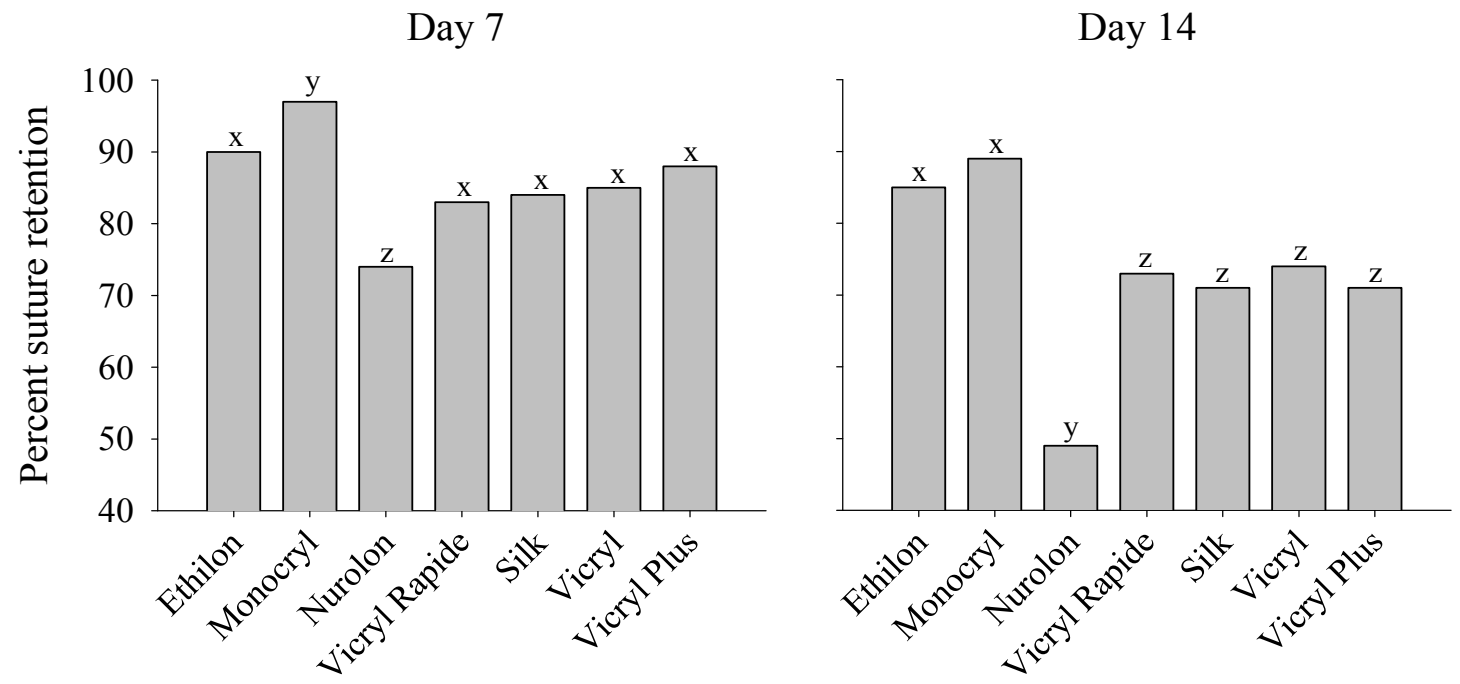

Suture Type

Figure 3.1. Percentage of suture retention for subyearling Chinook salmon by suture type at 7 and 14 days post-surgery. Similar letters indicate no significant $(P>0.05)$ differences in percentage of suture retention among suture types by day.

Retention of sutures differed significantly among surgeons $(P<0.001$; Figure 3.2$)$ and between water temperatures $(P<0.001)$ at 7 and $14 \mathrm{~d}$. Suture retention was significantly $(P<0.001)$ higher when surgeries were performed by surgeons 3 and 4 than surgeons 1 and 2 . Retention of sutures was not significantly $(P>0.05)$ different between surgeons 3 and 4 and was significantly $(P \leq 0.02)$ higher for surgeon 2 than surgeon 1 . At $7 \mathrm{~d}$, suture retention was significantly $(P<0.001)$ higher in water at $12^{\circ} \mathrm{C}$ $(94 \%)$ than at $17^{\circ} \mathrm{C}(78 \%)$. Similarly, retention of sutures at $14 \mathrm{~d}$ was significantly $(P<0.001)$ higher in $12^{\circ} \mathrm{C}$ water $(82 \%)$ than in $17^{\circ} \mathrm{C}(64 \%)$ water. 
Day 7

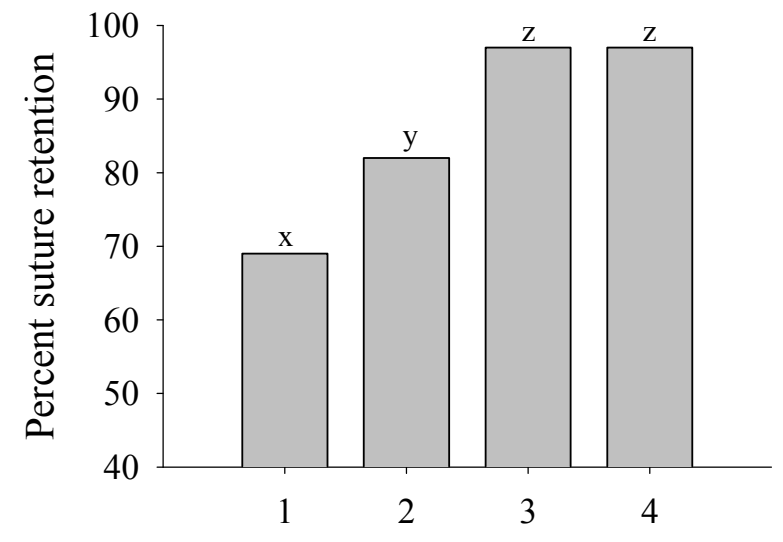

Day 14

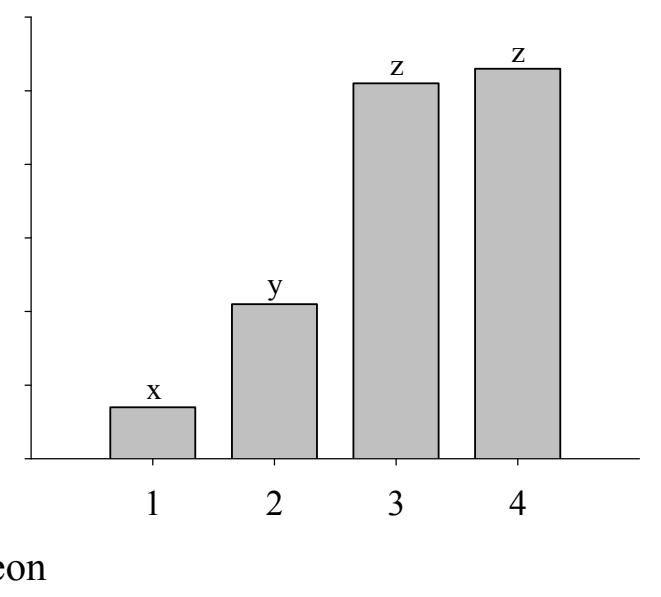

Figure 3.2. Percentage of suture retention for subyearling Chinook salmon by surgeon at 7 and 14 days post-surgery. Similar letters indicate no significant $(P>0.05)$ differences in percentage of suture retention among surgeons by day.

\subsection{Incision Openness}

Incision openness did not differ significantly $(P>0.05)$ among suture types at 7 or $14 \mathrm{~d}$ (Figure 3.3). However, incision openness was significantly influenced by suture retention $(P<0.001)$, surgeon $(P<$ $0.001)$, and water temperature $(P \leq 0.01)$ on both days. Mean incision openness decreased from 3.0 $( \pm 0.1)$ when no sutures remained to $1.5( \pm<0.1)$ when two sutures remained at $7 \mathrm{~d}$. A similar trend was observed at $14 \mathrm{~d}$ in which mean incision openness decreased from $2.2( \pm 0.1)$ when no sutures remained to $0.6 \pm(<0.1)$ when two sutures were retained. Mean incision openness varied among surgeons from 2.1 $( \pm<0.1)$ to $1.3( \pm<0.1)$ on day 7 and varied from $1.7( \pm<0.1)$ to $0.4( \pm<0.1)$ on day 14 . Incision openness was significantly $(P<0.001)$ lower in water at $12^{\circ} \mathrm{C}(1.5 \pm<0.1)$ than in $17^{\circ} \mathrm{C}(1.9 \pm<0.1)$ water at $7 \mathrm{~d}$. Similarly, at $14 \mathrm{~d}$, incision openness was significantly $(P=0.01)$ lower in $12^{\circ} \mathrm{C}$ water $(0.9 \pm<0.1)$ than in $17^{\circ} \mathrm{C}(1.0 \pm<0.1)$ water. 
Day 7

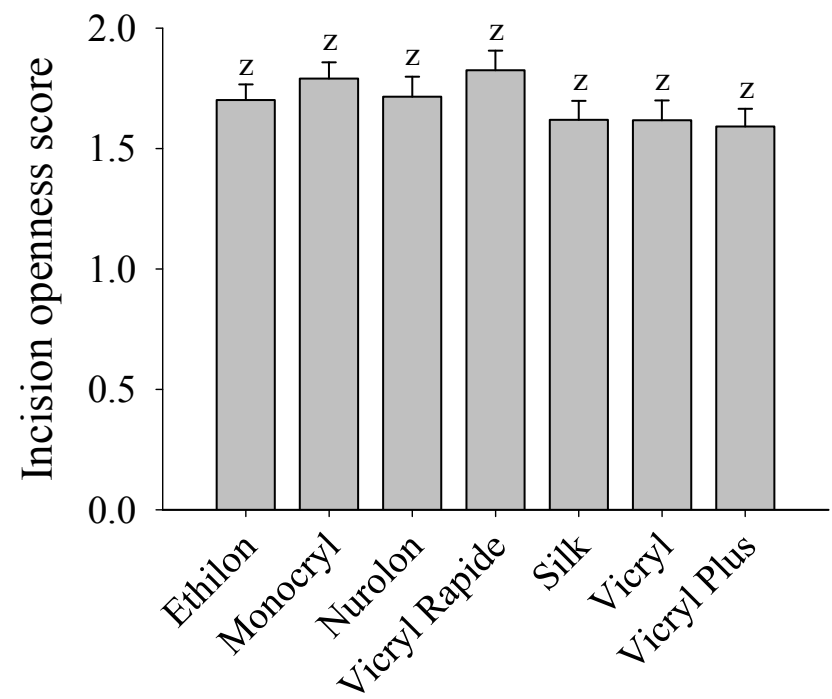

Day 14

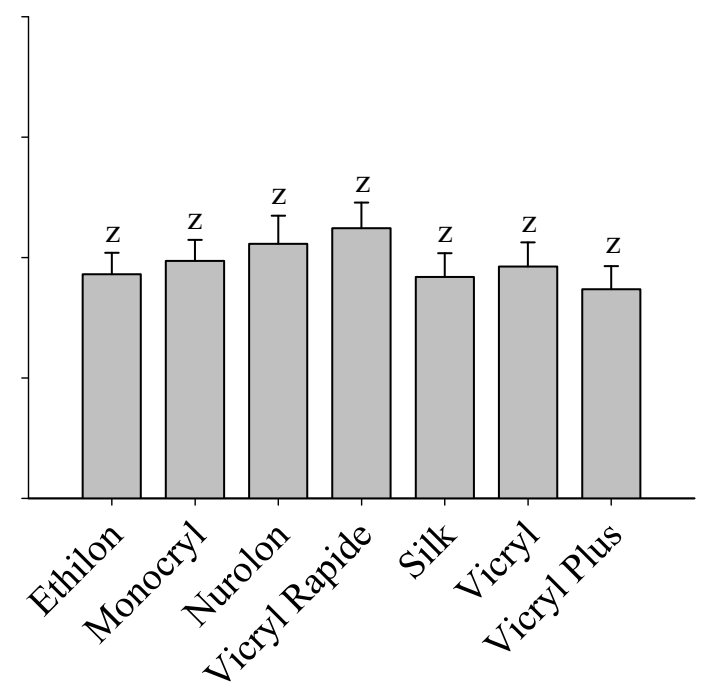

Suture Type

Figure 3.3. Mean incision openness score for subyearling Chinook salmon by suture type at 7 and 14 days post-surgery. Similar letters indicate no significant $(\mathrm{P}>0.05)$ differences in incision openness score among suture types by day. Error bars denote one standard error.

\subsection{Tag Retention}

Tag retention did not differ significantly $(P>0.05)$ among suture types on either day 7 or 14 (Figure 3.4). Retention of tags was influenced significantly by incision openness $(P<0.001)$, suture retention $(P<0.001)$, surgeon $(P<0.001)$, and water temperature $(P<0.001)$ at $14 \mathrm{~d}$. Tag retention was $100 \%$ in fish with no incision openness (score $=0$ ) and $42 \%$ in fish with an incision openness score of 4. Retention of tags was $68 \%, 94 \%$, and $99 \%$ when 0 , one, or two sutures were retained, respectively. Tag retention varied from $81 \%$ to $100 \%$ among surgeons and was significantly $(P<0.001)$ higher in $12^{\circ} \mathrm{C}$ $(99 \%)$ than $17^{\circ} \mathrm{C}(86 \%)$ water at $14 \mathrm{~d}$. 


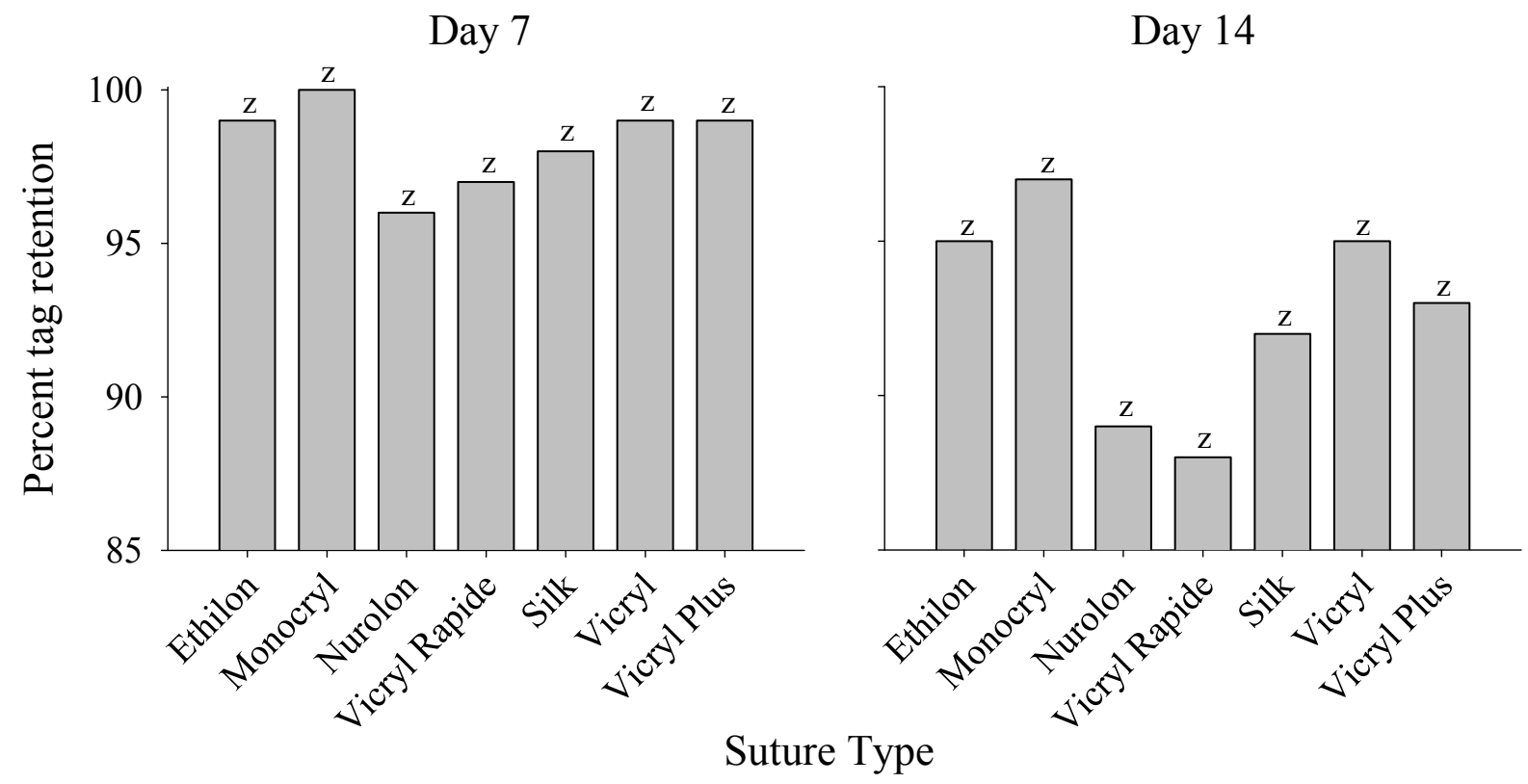

Figure 3.4. Percentage of tag retention for subyearling Chinook salmon by suture type at 7 and 14 days post-surgery. Similar letters indicate no significant $(P>0.05)$ differences in percentage of tag retention among suture types by day.

\subsection{Wound Inflammation}

Wound inflammation differed significantly $(P<0.001)$ among suture types at 7 and $14 \mathrm{~d}$ after surgery (Figure 3.5). Seven days after surgery, inflammation was significantly $(P \leq 0.002)$ lower for Monocryl, Ethilon, Vicryl Plus, and Nurolon than for Vicryl and silk. In addition, inflammation was significantly $(P$ $\leq 0.002$ ) lower for Monocryl, Ethilon, and Nurolon than for Vicryl Rapide. All other pairwise comparisons between suture types were not significantly $(P>0.05)$ different at $7 \mathrm{~d}$. Fourteen days after surgery, inflammation was lower $(P \leq 0.04)$ for Ethilon than all other suture types except Nurolon $(P=$ $0.45)$. Nurolon and Monocryl sutures produced significantly $(P<0.001)$ less inflammation than all three Vicryl types and silk. Inflammation did not differ significantly $(P=0.44)$ between Nurolon and Monocryl or any other pairwise comparison between suture types $(P>0.05)$ at $14 \mathrm{~d}$.

Wound inflammation differed significantly among surgeons $(P<0.001)$ at $7 \mathrm{~d}$ and between water temperature at $7 \mathrm{~d}(P<0.001)$ and $14 \mathrm{~d}(P=0.009)$. Mean wound inflammation varied from $1.6( \pm 0.1)$ to $3.0( \pm 0.1)$ among surgeons. Mean wound inflammation was significantly $(P<0.001)$ lower in $12^{\circ} \mathrm{C}$ $(1.5 \pm<0.1)$ than $17^{\circ} \mathrm{C}(3.4 \pm 0.1)$ water temperature at $7 \mathrm{~d}$. Similarly at $14 \mathrm{~d}$, wound inflammation was significantly $(P=0.01)$ lower in water at $12^{\circ} \mathrm{C}(3.9 \pm 0.1)$ than at $17^{\circ} \mathrm{C}(4.4 \pm 0.1)$. 
Day 7

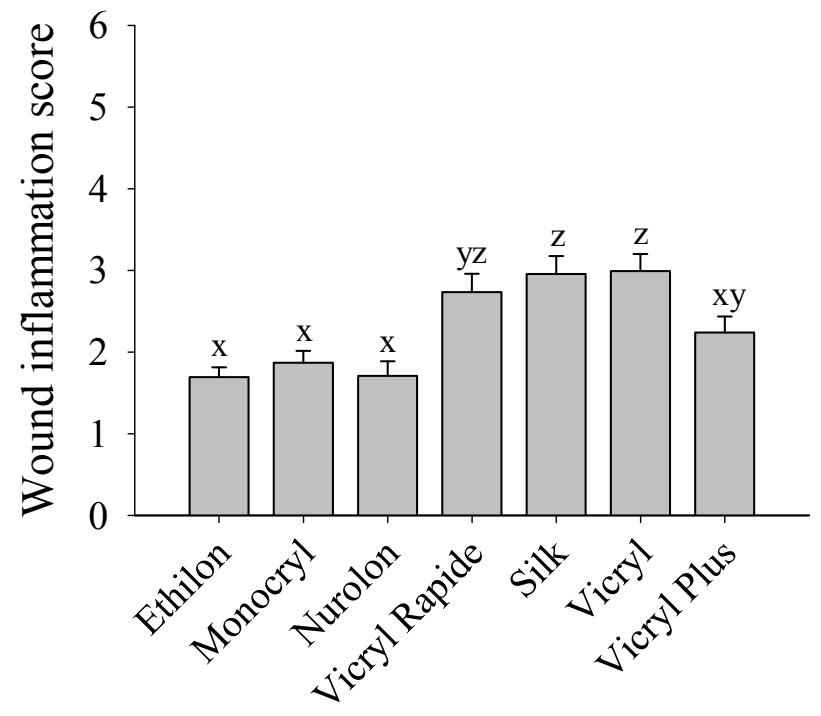

Day 14

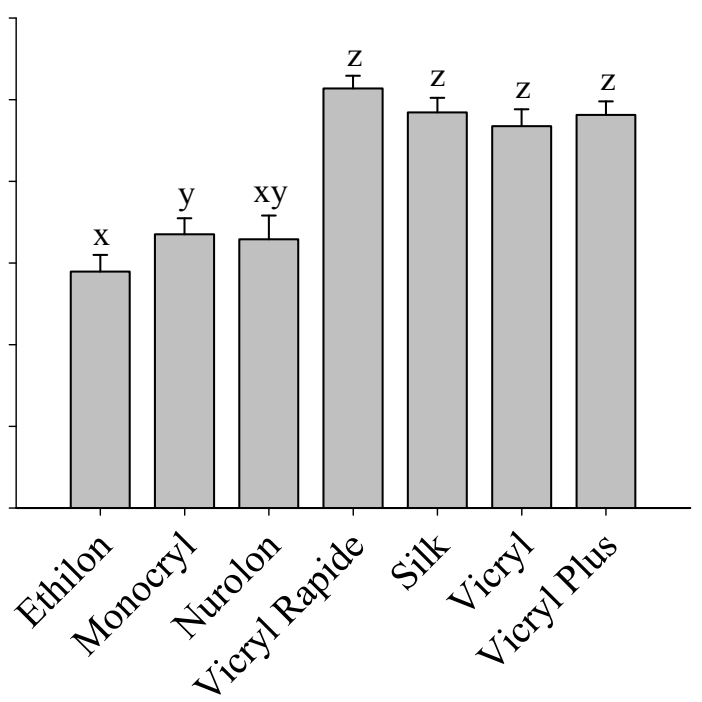

Suture Type

Figure 3.5. Mean wound inflammation for subyearling Chinook salmon by suture type at 7 and 14 days post-surgery. Similar letters indicate no significant $(P>0.05)$ differences in wound inflammation among suture types by day. Error bars denote one standard error.

\subsection{Wound Ulceration}

Wound ulceration was significantly $(P<0.001)$ different among suture types 7 and $14 \mathrm{~d}$ after surgery (Figure 3.6). Ethilon had significantly $(P \leq 0.01)$ less wound ulceration than all other suture types except Monocryl $(P=0.261)$ at day 7 . Monocryl caused significantly $(P \leq 0.002)$ less ulceration than all three Vicryl types and silk. Significantly $(P \leq 0.01)$ less ulceration occurred with Nurolon sutures than silk, Vicryl, and Vicryl Rapide sutures. By day 14 , wound ulceration was significantly $(P \leq 0.005)$ less with Nurolon, Ethilon, and Monocryl sutures than with all three Vicryl types and silk sutures.

Wound ulceration was significantly different among surgeons $(P \leq 0.02)$ and between water temperatures $(P<0.001)$ at 7 and $14 \mathrm{~d}$. Mean wound ulceration varied among surgeons from $0.2( \pm<0.1)$ to $1.2( \pm 0.1)$ on day 7 and varied from $2.1( \pm 0.2)$ to $3.0( \pm 0.2)$ on day 14. Mean wound ulceration was significantly $(P<0.001)$ lower in $12^{\circ} \mathrm{C}(0.1 \pm<0.1)$ than $17^{\circ} \mathrm{C}(1.7 \pm 0.1)$ water temperature at $7 \mathrm{~d}$. Similarly at $14 \mathrm{~d}$, wound ulceration was significantly $(P<0.001)$ lower in $12^{\circ} \mathrm{C}(2.3 \pm 0.1)$ than $17^{\circ} \mathrm{C}(3.3$ \pm 0.2 ) water temperature. 


\section{Day 7}

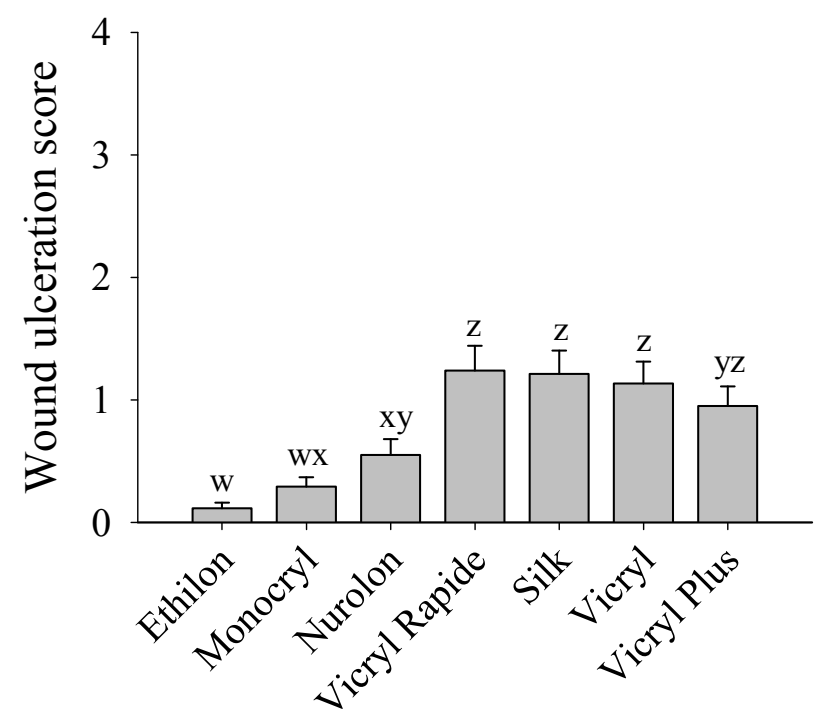

Day 14

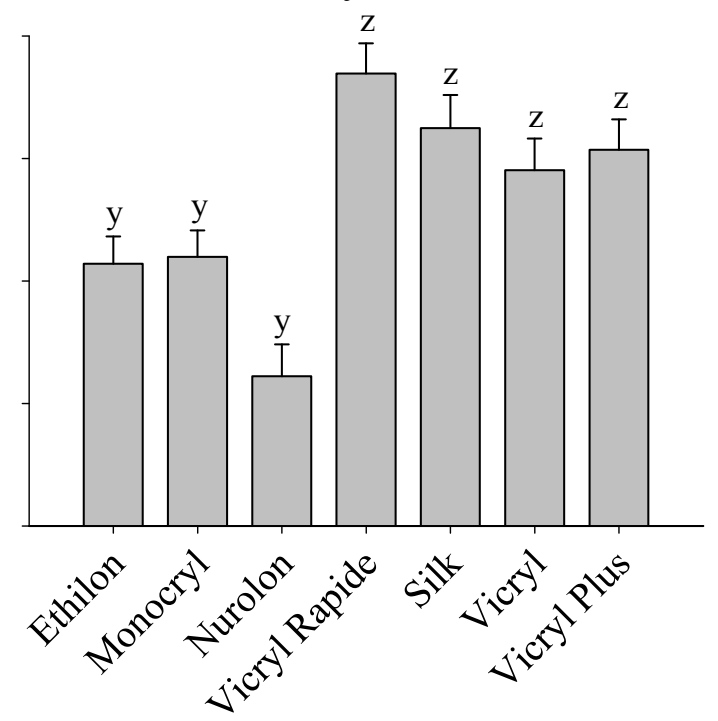

Suture Type

Figure 3.6. Mean wound ulceration for subyearling Chinook salmon by suture type at 7 and 14 days post-surgery. Similar letters indicate no significant $(P>0.05)$ differences in wound ulceration among suture types by day. Error bars denote one standard error. 


\subsection{Discussion}

Suture retention was highest for monofilament sutures. Monofilament sutures, Ethilon and Monocryl, exhibited higher suture retention than braided suture types by day 14 . However at day 7, only the absorbable monofilament suture (Monocryl) had higher retention than other suture types. Monofilament sutures may reduce wicking of bacteria into the peritoneal cavity and elicit a lesser foreign body response (Hurty et al. 2002), thus minimizing inflammation in the body wall and enabling sutures to remain intact longer. Retention of nonabsorbable monofilament (Ethilon) and silk sutures was similar at $7 \mathrm{~d}$ in this study. Similarly, $5 \mathrm{~d}$ after surgery, suture retention did not differ between nonabsorbable monofilament and silk sutures in juvenile largemouth bass implanted with radio microtransmitters (Cooke et al. 2003).

Wound inflammation and ulceration were generally lower for Ethilon and Monocryl than for most of the braided sutures. In this study, Nurolon (braided) exhibited low wound inflammation and ulceration at $14 \mathrm{~d}$ post-surgery, although suture retention was poor. Similar studies with rainbow trout have reported lower levels of inflammation associated with monofilament sutures than with other suture types (Kaseloo et al. 1992; Wagner et al. 2000). Histological studies also reported lower inflammation with absorbable monofilament in koi (Hurty et al. 2002). Interestingly, Hurty et al. (2002), found nylon monofilament (Ethilon) to have a grossly observable reaction with koi skin over 14 days. If Ethilon did react with the skin of Chinook salmon in this study, the reaction was not grossly apparent. This result indicates possible differences between species may affect suture performance.

Cooler water temperature $\left(12^{\circ} \mathrm{C}\right)$ during holding resulted in better overall post-surgery characteristics (i.e., higher suture and tag retention and lower incision openness, wound inflammation, and ulceration) in juvenile Chinook salmon than warmer water temperature $\left(17^{\circ} \mathrm{C}\right)$. Similarly, bluegills had higher tag retention and lower tissue inflammation at incision and suture sites when held at $6^{\circ} \mathrm{C}$ than $18^{\circ} \mathrm{C}(\mathrm{Knights}$ and Lasee 1996). Inflammatory responses have been shown to be slower at $5^{\circ} \mathrm{C}$ than $15^{\circ} \mathrm{C}$ in rainbow trout (Finn and Nielsen 1971). In addition, Bunnell and Isely (1999) observed higher rates of tag loss in brown trout in $20^{\circ} \mathrm{C}$ than $10^{\circ} \mathrm{C}$ water. Although water temperature significantly influenced incision openness in this study, since the differences in openness scores were relatively small, biological importance of this result may be negligible.

We found a significant effect of surgeon on suture retention, incision openness, and tag retention. Suture retention among suture types was lower and more variable for surgeons 1 and 2 compared to surgeons 3 and 4 (Figure 4.1). Surgeons in this study were initially thought to have similar surgical proficiency based on extensive previous experience. Experience for surgeons 3 and 4 included laboratory-based studies, in which healing and transmitter loss were monitored for several weeks. These surgeons obtained feedback on their surgical techniques, which allowed them to remediate areas of lesser surgical proficiency (e.g., suture placement and tightness, knotting ability). Previously, surgeons 1 and 2 had performed a very large number of surgeries in field studies but were not allowed the benefit of observing the effects of their surgical techniques on factors associated with incision healing.

The majority (62\%) of surveyed fisheries researchers performing surgical implantation in telemetry projects felt effects of surgeon performance were large enough to include surgeon as a variable in analyses (Wagner and Cooke 2005). Although experience can be a predictor of surgical competence (Cooke et al. 2003), this study suggests surgical volume (number of surgeries performed) should not be the only measure of aptitude. Training for potential surgeons should include visual feedback whenever 
possible. Feedback could include a series of photographs documenting the condition of sutures and surrounding tissue taken on surgery and post-surgery days (prior to considerable healing). Areas of surgical technique needing improvement could be identified and remediated. Differences among surgeons could be minimized and proficiency increased if surgeons are able to acquire feedback after performing surgeries.

Day 14
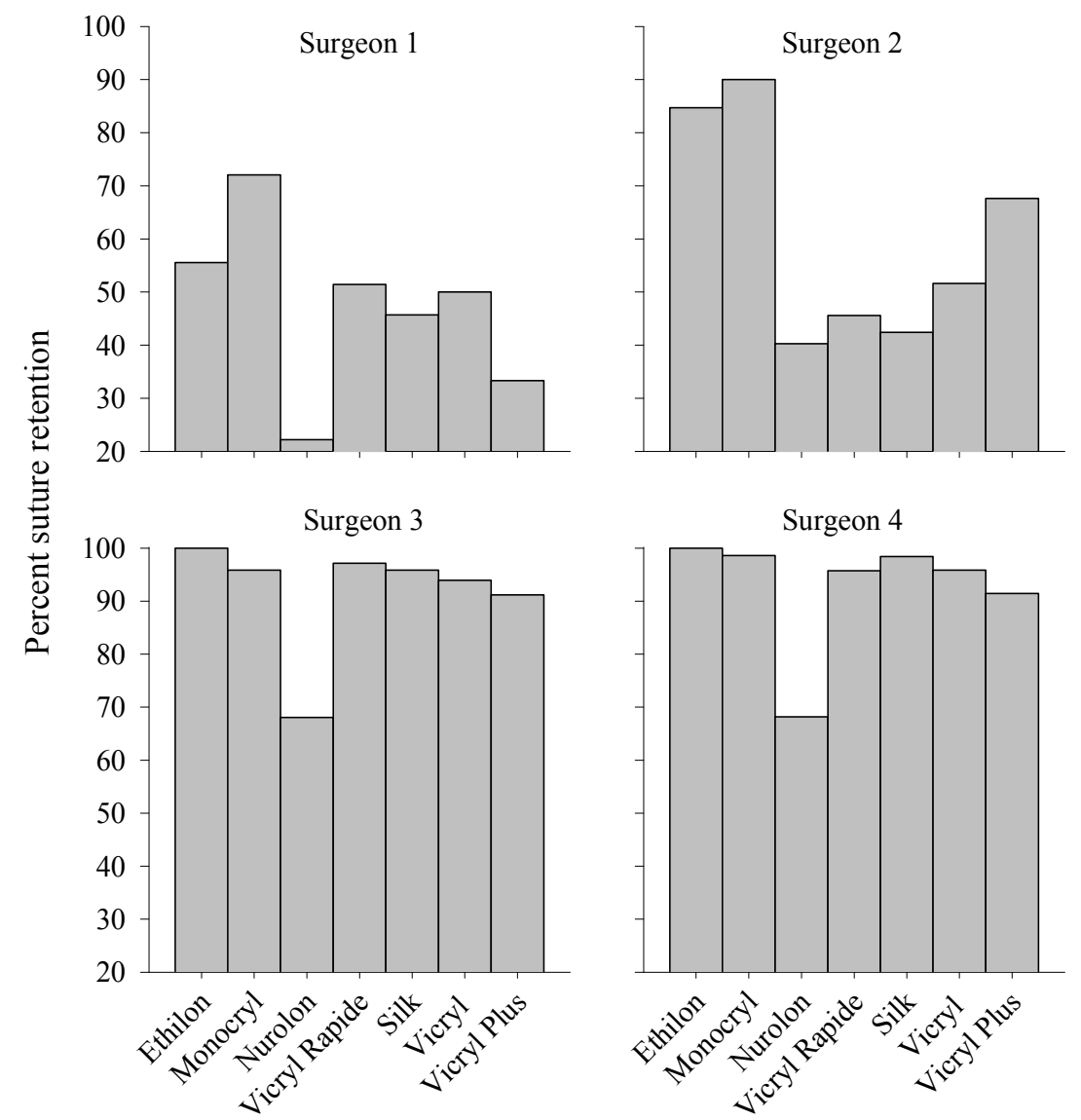

Suture Type

Figure 4.1. Percentage of suture retention for subyearling Chinook salmon by suture type and surgeon 14 days post-surgery.

Overall, monofilament sutures (Monocryl and Ethilon) were retained better than all other suture types up to $14 \mathrm{~d}$ following surgery. Variability among surgeons was influential in dictating suture retention; surgeons who had received feedback on previous surgeries were associated with higher suture retention. Higher suture retention resulted in higher tag retention. This latter effect has a positive economic ramification: lower transmitter loss allows for tagging fewer fish while maintaining statistical power in analysis, thereby decreasing project costs.

In addition to having higher retention, Monocryl and Ethilon were equal to or better than all other suture types with respect to levels of tissue inflammation and ulceration up to $14 \mathrm{~d}$ after surgery. Because some researchers have seen undesirable effects from long-term retention of nonabsorbable sutures (Jepsen 
et al. 2007), we conclude that absorbable Monocryl is the best suture material to close an incision created by surgical implantation of acoustic transmitters in subyearling Chinook salmon. 



\subsection{References}

Absolon RF, MB Eppard, BP Sandford, GA Axel, EE Hockersmith, and JW Ferguson. 2003. Effects of Turbines Operating at Two Different Discharge Levels on Survival and Condition of Yearling Chinook Salmon at McNary Dam, 2002. Northwest Fisheries Science Center, Seattle, Washington.

Adams NS, DW Rondorf, and EE Kofoot. 1996. Migrational Characteristics of Juvenile Spring Chinook Salmon and Steelhead in the Forebay of Lower Granite Dam Relative to the 1996 Surface Bypass Collector Tests. Report to the U.S. Army Corps of Engineers, Walla Walla District, Walla Walla, Washington.

Adams NS, DW Rondorf, and EE Kofoot. 1997. Migrational Characteristics of Juvenile Spring Chinook Salmon and Steelhead in the Forebay of Lower Granite Dam Relative to the 1997 Surface Bypass Collector Tests. Report to the U.S. Army Corps of Engineers, Walla Walla District, Walla Walla, Washington.

Anglea S, T Poe, and A Giorgi. 2001. Synthesis of Radio Telemetry, Hydroacoustic, and Survival Studies of Juvenile Salmon at John Day Dam (1980-2000). Report to U.S. Army Corps of Engineers, Portland District, Portland, Oregon.

Axel GA, EE Hockersmith, MB Eppard, and BP Sandford. 2004a. Passage and Survival of Hatchery Yearling Chinook Salmon at McNary Dam, 2002. Northwest Fisheries Science Center, Seattle, Washington.

Axel GA, EE Hockersmith, MB Eppard, and BP Sandford. 2004b. Passage and Survival of Hatchery Yearling Chinook Salmon at McNary Dam, 2003. Northwest Fisheries Science Center, Seattle, Washington.

Boothe HW. 2003. Suture materials, tissue adhesives, staples and ligating clips. In Textbook of Small Animal Surgery, DH Slatter (ed), pp. 235-243. Saunders, Philadelphia.

Brown RS, DR Geist, KA Deters, and A Grassell. 2006. Effects of surgically implanted acoustic transmitters $>2 \%$ of body mass on the swimming performance, survival and growth of juvenile sockeye and Chinook salmon. Journal of Fish Biology 69:1626-1638.

Brown RS, KM Carter, KA Deters, and CA McKinstry. 2007. Determination of a minimum fish size for implantation with a Juvenile Salmonid Acoustic Telemetry System (JSATS) tag. In Comparative Performance of Acoustic-Tagged and Passive Integrated Transponder-Tagged Juvenile Salmonids, EE Hockersmith, RS Brown, and TL Liedtke (eds), pp. 71-82. Northwest Fisheries Science Center, Seattle, Washington.

Bunnell DB and JJ Isely. 1999. Influence of temperature on mortality and retention of simulated transmitters in rainbow trout. North American Journal of Fisheries Management 19:152-154.

Cooke SJ, BDS Graeb, CD Suski, and KG Ostrand. 2003. Effects of suture material on incision healing, growth, and survival of juvenile largemouth bass implanted with miniature radio transmitters: case study of a novice and experienced fish surgeon. Journal of Fish Biology 62:1360-1388. 
Eppard MB, BP Sandford, EE Hockersmith, GA Axel, and DB Dey. 2005a. Spillway Passage Survival of Hatchery Yearling and Subyearling Chinook Salmon at Ice Harbor Dam, 2002. Northwest Fisheries Science Center, Seattle, Washington.

Eppard MB, BP Sandford, EE Hockersmith, GA Axel, and DB Dey. 2005b. Spillway Passage Survival of Hatchery Yearling and Subyearling Chinook Salmon at Ice Harbor Dam, 2003. Northwest Fisheries Science Center, Seattle, Washington.

Ethicon. 2005. Wound Closure Manual. Ethicon Inc. Somerville, New Jersey.

Finn JP and NO Nielsen. 1971. The effect of temperature variation on the inflammatory response of rainbow trout. Journal of Pathology 105: 257-268.

Gilliland ER. 1994. Comparison of absorbable sutures used in largemouth bass liver biopsy surgery. The Progressive Fish Culturist 56:60-61.

Hockersmith EE, GA Axel, MB Eppard, DA Ogden, and BP Sandford. 2005. Passage Behavior and Survival for Hatchery Yearling Chinook Salmon at Lower Monumental Dam, 2004. Northwest Fisheries Science Center, Seattle, Washington.

Hurty CA, DC Brazic, JM Law, K Sakamoto, and GA Lewbart. 2002. Evaluation of the tissue reactions in the skin and body wall of koi (Cyprinus carpio) to five suture materials. Veterinary Record 151:324328.

Jepsen N, JS Mikkelsen, and A Koed. 2007. Effects of tag and suture type on survival and growth of brown trout with surgically implanted telemetry tags in the wild. Journal of Fish Biology 72:594-602.

Kaseloo PA, AH Weatherly, J Lotimer, and MD Farina. 1992. A biotelemetry system recording fish activity. Journal of Fish Biology 40:165-179.

Knights BC and BA Lasee. 1996. Effects of implanted transmitters on adult bluegills at two temperatures. Transactions of the American Fisheries Society 125:440-449.

Lin PH, MK Hirko, JA von Fraunhofer, and HP Greisler. 1996. Wound healing and inflammatory responses to biomaterials. In Wound Closure Biomaterials and Devices, CC Chu, JA von Fraunhofer, and HP Greisler (eds), pp. 7-24. CRP Press, Ithaca, New York.

Lucas MC. 1989. Effects of implanted dummy transmitters on mortality, growth and tissue reaction in rainbow trout, Salmo gairdneri Richardson. Journal of Fish Biology 35:577-587.

Moore A, IC Russell, and ECE Potter. 1990. The effects of intraperitoneally implanted dummy acoustic transmitters on the behavior and physiology of juvenile Atlantic salmon, Salmo salar L. Journal of Fish Biology 37:713-721.

Ploskey G, T Poe, A Giorgi, and G Johnson. 2001. Synthesis of Radio Telemetry, Hydroacoustic, and Survival Studies of Juvenile Salmon at the Dalles Dam (1982-2000). PNWD-3131, Battelle-Pacific Northwest Division, Richland, Washington. 
Robertson MJ, DA Scruton, and JA Brown. 2003. Effects of surgically implanted transmitters on swimming performance, food consumption and growth of wild Atlantic salmon parr. Journal of Fish Biology 62:673-678.

Roush JK. 2003. Biomaterials and surgical implants. In Textbook of Small Animal Surgery, 3rd ed., DH Slatter (ed), pp. 141-148. Saunders, Philadelphia.

Summerfelt RC and LS Smith. 1990. Anesthesia, surgery, and related techniques. In Methods for Fish Biology, CB Schreck and PB Moyle (eds), pp. 213-263. American Fisheries Society, Bethesda, Maryland.

Thoreau X and E Baras. 1997. Evaluation of surgical procedures for implanting telemetry transmitters in to the body cavity of tilapia Oreochromis aureus. Aquatic Living Resources 10:207-211.

Wagner GN, ED Stevens, and P Byrne. 2000. Effects of suture material and patterns on surgical wound healing in rainbow trout. Transactions of the American Fisheries Society 129:1196-1205.

Wagner GN and SJ Cooke. 2005. Methodological approaches and opinions of researchers involved in the surgical implantation of telemetry transmitters in fish. Journal of Aquatic Animal Health 17:160-169.

Winter JD. 1996. Advances in underwater biotelemetry. In Fisheries Techniques, 2nd ed., BR Murphy and DW Willis (eds), pp. 555-590. American Fisheries Society, Bethesda, Maryland. 




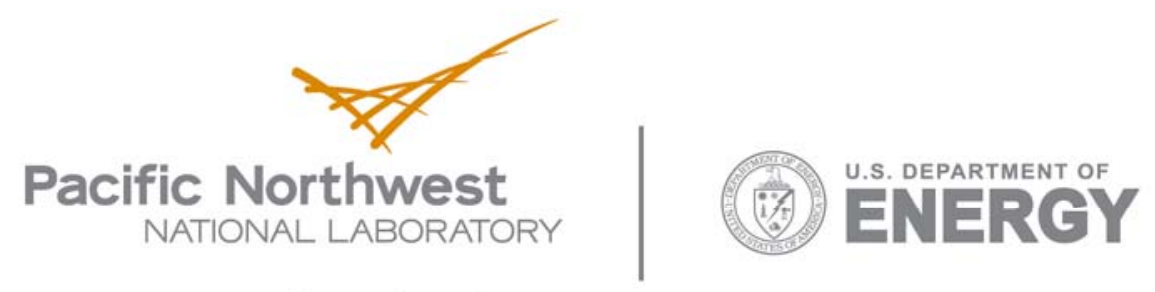

902 Battelle Boulevard

P.O. Box 999

Richland, WA 99352

1-888-375-PNNL (7665)

www.pnl.gov 